\section{Assessment of metal contaminants in non-small cell lung cancer by EDX microanalysis}

M. Scimeca, ${ }^{1}$ A. Orlandi, ${ }^{1}$ I. Terrenato, ${ }^{2}$

S. Bischetti, ${ }^{1}$ E. Bonanno'

${ }^{1}$ Anatomic Pathology Section,

Department of Biomedicine and

Prevention, University of Rome

Tor Vergata

${ }^{2}$ Regina Elena National Cancer Institute, Biostatistic Unit-Scientific Direction,

Rome, Italy

\section{Abstract}

Human cardio-respiratory diseases are strongly correlated to concentrations of atmospheric elements. Bioaccumulation of heavy metals is strictly monitored, because of its possible toxic effects. In this work, we utilized the EDX microanalysis in order to identify the potential heavy metal accumulation in the lung tissue. To this aim, we enrolled 45 human lung biopsies: 15 non-small cell lung cancers, 15 lung benign lesions and 15 control biopsies. Lung samples were both paraffin embedded for light microscopy study and epon-epoxid embedded for transmission electron microscopy. EDX microanalysis was performed on $100 \mathrm{~nm}$ thick unstained ultrathin-sections placed on specific copper grids. Our results demonstrated that the EDX technology was particularly efficient in the study of elemental composition of lung tissues, where we found heavy metals, such as Cobalt (Co), Chromium $(\mathrm{Cr})$, Manganese $(\mathrm{Mn})$ and Lead $(\mathrm{Pb})$. Furthermore, in malignant lesions we demonstrated the presence of multiple bio-accumulated elements. In fact, a high rate of lung cancers was associated with the presence of 3 or more bio-accumulated elements compared to benign lesions and control tissue $(91.7 \%, 0 \%$, $8.3 \%$, respectively). The environmental impact on pulmonary carcinogenesis could be better clarified by demonstrating the presence of polluting agents in lung tissues. The application of EDX microanalysis on biological tissues could shed new light in the study of the possible bioaccumulation of polluting agents in different human organs and systems.

\section{Introduction}

Active cigarettes smoking, occupational exposures, residential radon, and environmental tobacco smoke are risk factors for lung cancer, which is the most common cause of cancer death worldwide. ${ }^{1}$ Air pollutants, especially particulate substances, such as polycyclic aromatic hydrocarbons and other genotoxic chemicals, are suspected to increase the risk of lung cancer. ${ }^{2,3}$

In the large urban centers of many industrialized countries, a strong correlation has been identified between mortality caused by cardiorespiratory diseases and atmospheric concentrations of particulate matter (from particles below $10 \mu \mathrm{m}$, called PM 10, to smaller ones, the PM 2.5) ${ }^{4,5}$ In the last few years, numerous studies postulated the synergistic effects of oxidative stress and inflammation, as being the major biochemical pathways of PMinduced toxicity and health effects. ${ }^{6,7}$ The depth of penetration and deposition of PM depends on the particle size, shape and density. ${ }^{8}$ Beside these physical parameters, PMinduced toxicity is also affected by its chemical composition and source. ${ }^{9}$ Among the elements which constitute PM 10 and PM 2.5, heavy metals share possible toxic effects induced by their bio-accumulation. In vitro experimental data suggest heavy metal toxicity and that the onset of metal poisoning could be accompanied by recognizable acute symptoms. ${ }^{10}$

Cobalt and its compounds induced aneuploidies, micronuclei and chromosome aberrations in the bone marrow in rodents after intra-tracheal infusion ${ }^{11}$ and mutations of the K-ras. ${ }^{12}$ The exposure to chromium (VI) compounds is consistently associated with the incidence of lung cancers both in experimental models and in humans. ${ }^{13}$ Lead exposure can occur by inhalation or ingestion. These substances are distributed throughout the body via the blood stream. The toxic nature of lead is well-documented and is known to affect all organs and functions. ${ }^{14}$ Manganese, an essential element for human health in trace amounts, is toxic at high doses. Since manganese is globally replacing lead in gasoline, an evaluation of its potential cancer effects is relevant. ${ }^{15}$

Despite this data, the long-term effects of bioaccumulation of heavy metals and their involvement in human chronic diseases are still controversial.

The aim of this work is to investigate the presence of toxic elements, such as $\mathrm{Co}, \mathrm{Cr}, \mathrm{Mn}$, and $\mathrm{Pb}$ in the lung tissue explored by EDX microanalysis. This data could enable us to correlate the presence of these elements in the lung tissues with pulmonary diseases.

\section{Materials and Methods}

\section{Histological analysis}

In this retrospective study, we selected 45
Corresponding author: Dr. Elena Bonanno, Department of Biomedicine and Prevention, University of Rome Tor Vergata, Via Montpellier 1, 00133 Rome, Italy.

Tel. +39.06.20903913.

E-mail: elena.bonanno@uniroma2.it

Key words: EDX microanalysis, transmission electron microscopy, non-small cell lung cancer, heavy metals, environmental pollution.

Conflict of interests: the authors declare no conflict of interest.

Contributions: MS, AO, EB, conceived, carried out experiments and analyzed data; IT, SB, carried out experiments and analyzed data; MS and AO equally contributed to the work. All authors were involved in writing the paper and gave final approval of the submitted and published versions.

Acknowledgments: the authors wish to thank Prof. Luigi Giusto Spagnoli for introducing the EDX microanalysis in our laboratory, encouraging and sustaining them in setting up the phases of this technique and Dr. Alessia Lucia Muzi for the helpful discussions in planning stages of the work.

Received for publication: 31 March 2014 Accepted for publication: 7 July 2014.

This work is licensed under a Creative Commons Attribution NonCommercial 3.0 License (CC BYNC 3.0).

(C) Copyright M. Scimeca et al., 2014

Licensee PAGEPress, Italy

European Journal of Histochemistry 2014; 58:2403 doi:10.4081/ejh.2014.2403

consecutive human lung biopsies from our archive (Table 1). All biopsies were fixed with $10 \%$ buffer formalin and paraffin embedded; 4 $\mu$-thick sections were stained with hematoxylyn and eosin (H\&E). ${ }^{16}$ Two pathologists blindly classified the tissues.

\section{Immunohistochemistry}

The phenotype of neoplasia was characterized by the presence of cytokeratin $5 / 6$ and p 63 (typically expressed by squamous cell carcinomas) and by the thyroid transcription factor 1 (TTF-1) and cytokeratin 7 (typically expressedby adenocarcinomas). Immunohistochemistry was performed by Bench Mark automatized system (Ventana, Tucson, AZ, USA). Briefly, 4$\mu$ m-thick sections were pre-treated with $\mathrm{CCl}$ reagent (Ventana) for $30 \mathrm{~min}$ at $95^{\circ} \mathrm{C}$ and then incubated respectively with mouse monoclonal anti-Cytokeratin $5 / 6$ for 30 min (pre-diluted clone D5/16B4, Ventana), rabbit monoclonal anti-Cytokeratin 7 for 30 min (pre-diluted clone SP52, Ventana), mouse monoclonal antip63 for $40 \mathrm{~min}$ (pre-diluted clone 4A4, 
Ventana) and rabbit monoclonal anti-TTF-1 for 30 min (pre-diluted clone SP141, Ventana). Washings were performed with reaction buffers produced by Ventana; reactions were revealed by ultraView Universal DAB Detection Kit (Ventana).

\section{Ultrastructural analysis}

Lung samples were $4 \%$ paraformaldehyde fixed, $2 \%$ osmium tetroxide post-fixed and embedded in epon resin as previously reported. ${ }^{17}$ After washing $0.1 \mu \mathrm{M}$ with a phosphate buffer, tissues were dehydrated by $30 \%, 50 \%$, $70 \%, 95 \%$ and absolute ethanol. After the short propylene oxide incubation, samples were embedded in epon epoxy resin (Agar Scientific, Stansted Essex CM24 8GF United Kingdom). ${ }^{18}$ Eponepoxide resin embedded tissues were sectioned ${ }^{18}$ and stained with uranyl acetate and lead citrate as previously described..$^{19}$

All samples were examined by a transmission electron microscope Hitachi H-7100 FA (Hitachi, Schaumburg, IL, USA).

\section{EDX microanalysis}

The EDX microanalysis is a technology that performs the elemental and chemical analysis of a sample in transmission electron microscopy. When the electron beam in an electron microscope hits a thin sample, some atoms of the sample will be excited or ionized. When they return to their ground state, they will emit characteristic $\mathrm{x}$-rays. The $\mathrm{x}$-ray emission at different wavelengths may then be measured by a photon-energy-sensitive detector. The EDX detector system performs a simultaneous display of all mid-energy (1-20 keV) xrays collected during any individual analysis period. Therefore it is possible to detect those elements with $\mathrm{AN}>10$. The minimal detectable elemental concentration, which requires some signal averaging, is approximately $0.1 \mathrm{mmol}$ per kg of dry specimen (i.e., $10 \mathrm{ppm}$ ), whereas spatial resolution ranges from about $10 \mathrm{~nm}$ to a few micrometers. For the EDX microanalysis $100 \mathrm{~nm}$-thick unstained ultrathin sections were placed on specific copper grids. The EDX spectra were acquired by a Hitachi 7100FA transmission electron microscope and an EDX detector (Thermo Scientific) at an acceleration voltage of $75 \mathrm{KeV}$ and 12000 magnification. Spectra were semi-quantitatively analyzed by the Noram System Six software (Thermo Scientific, Waltham, MA USA) using the standardless Cliff-Lorimer k-factor method. ${ }^{20}$ The EDX microanalysis system was calibrated using the $\mathrm{x}$-ray microanalysis standard (Micro-Analysis Consultants Ltd, Cambridgeshire UK). The EDX system was set up to detect $\mathrm{Co}, \mathrm{Cr}$, Mn and $\mathrm{Pb}$. Water pollutant elements like As were excluded from the analysis, since they are contaminants of the

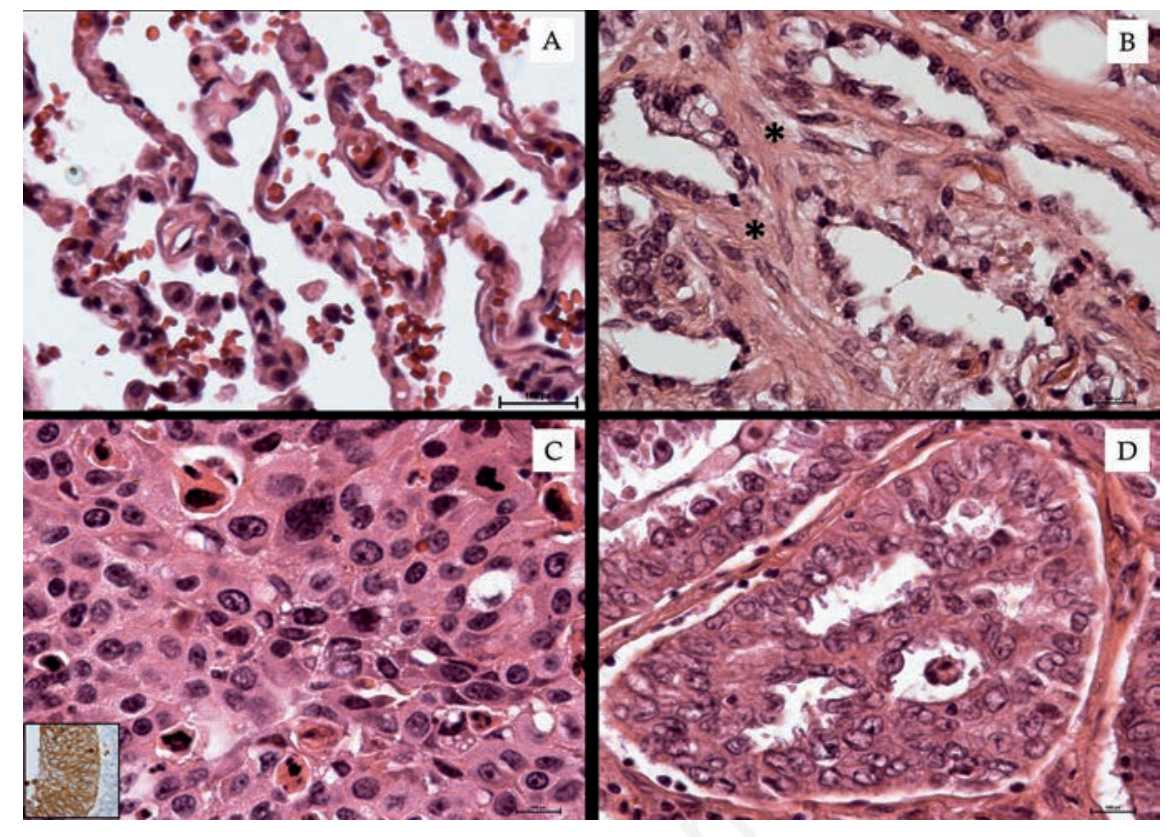

Figure 1. Lung tissue morphological study. A) Normal lung tissue characterized by alveoli with thin walls. B) Pulmonary fibrosis; asterisks indicate collagen deposition in the alveolar septa. C) Squamous cell carcinoma (inset shows Cytokeratin 5/6 positivity). D) Well differentiated adenocarcinoma.
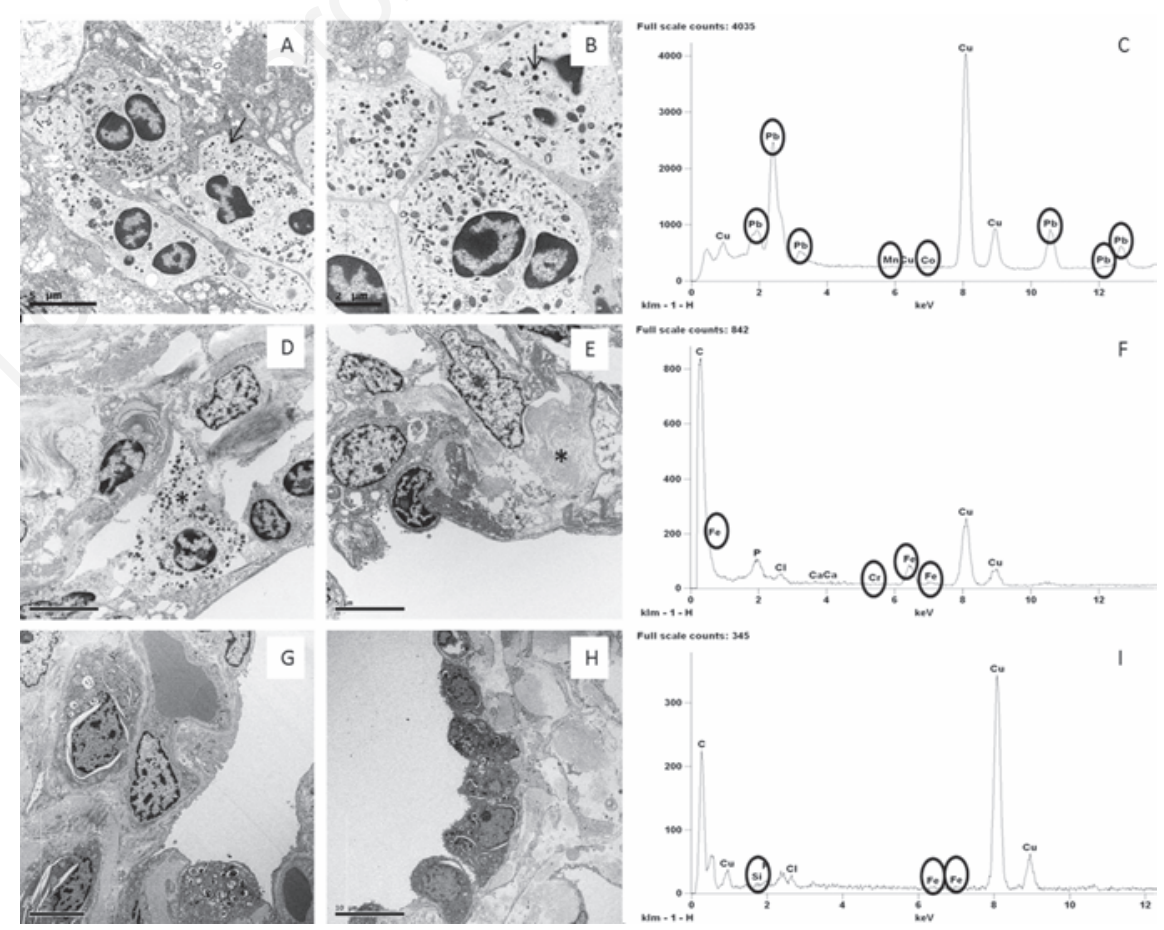

Figure 2. Ultrastructural and EDX analysis of lung tissues. A,B) Lung adenocarcinoma cells with dense granules 400 to $600 \mathrm{~nm}$ in diameter (arrow) and large nucleoli. C) Toxic elements detected in one case of NSCLC. D) Inflammatory infiltrates (asterisk indicate a mastocyte) in interstitium of BL tissue. E) Chronic interstitial pneumonia; note lung cells and collagen deposition (asterisk). F) Toxic elements detected in one case of benign lesion. G,H) Lung tissues without significant pulmonary pathology. I) Toxic elements detected in one case of control tissues. 
buffer solutions used during histological sample preparation.

The sample standards used as controls were: Dural (Al, $\mathrm{Cu}, \mathrm{Mg})$, Apatite $\left(\mathrm{Ca}_{5}\left(\mathrm{PO}_{4}\right) 3(\mathrm{OH})\right.$ ), Lead Sulphide ( $\mathrm{PbS})$, Chromite $\left(\mathrm{FeCr}_{2} \mathrm{O}_{4}\right)$, Chromium (Cr), Iron (Fe), Manganese (Mn), Silicon (Si), Tungsten (W), Zinc (Zn), Cadmium sulfide (CdS) and Cobalt (Co). For each sample, the microanalysis acquisition was performed in 15 fields selected randomly.

\section{Animal model}

To assess the ability of the EDX microanalysis to detect the accumulation of inhaled metals into the biological tissues, 4 mice, C57 black strain, were exposed to $\mathrm{SiO}_{2}$ particles. All experiments were approved by the Institutional Animal Care and Use Committee (IACUC) and carried out according to the Italian and European rules (Leg. Decree 116/92; EC 609/86; European Directive 2010/63/EU). Mice were exposed to $\mathrm{SiO}_{2}$ dusts for periods of 15,30 , and 50 days in chambers equipped with conical-type dust generators. The animals were exposed to the dusts for $6 \mathrm{~h}$ a day, 3 days a week.

\section{Statistical analysis}

Descriptive statistics was used to summarize pertinent study information. Categorical variables were reported as frequencies and percentage values, whereas continuous variables were summarized by mean values and their relative standard deviations.

Correlations between categorical variables were evaluated through non-parametric tests, such as the Pearson's Chi-Square test or the Fisher exact test, when appropriate. P-values $<0.05$ denote statistically significant correlations. Statistical analyses were carried out using the SPSS software (SPSS ver. 21.0, SPSS Inc., Chicago, IL, USA).

\section{Results}

\section{Morphological analysis}

The study of H\&E sections, immunostaining reactions and ultrastructural characterizations allowed us to classify human lung biopsies according to WHO 2012 as follows: 15 nonsmall cell lung cancers (NSCLC) classified as adeno-carcinomas (9 cases) and squamous cell carcinomas (6 cases), 15 benign lung lesions (BL) classified as chronic interstitial pneumonia (8 cases), idiopathic pulmonary fibrosis (5 cases) and adipose fibrosis (2 cases), and 15 lung tissue from patients negative for pulmonary pathology (Controls) (Figures 1 and 2).

NSCLC cases included 10 male patients and 5 female patients (mean age 60.13 \pm 2.54 years), among them 12 were smokers. The BL group was composed of 12 male and 3 female patients (mean age $66.53 \pm 2.05$ years), among them 10 were smokers. Control group consisted of 8 male and 7 female patients (mean age $66.14 \pm 1.77$ years), 10 among them were smokers (Table 1). Mouse lung tissues showed fibrotic and inflammatory reactions (not shown).
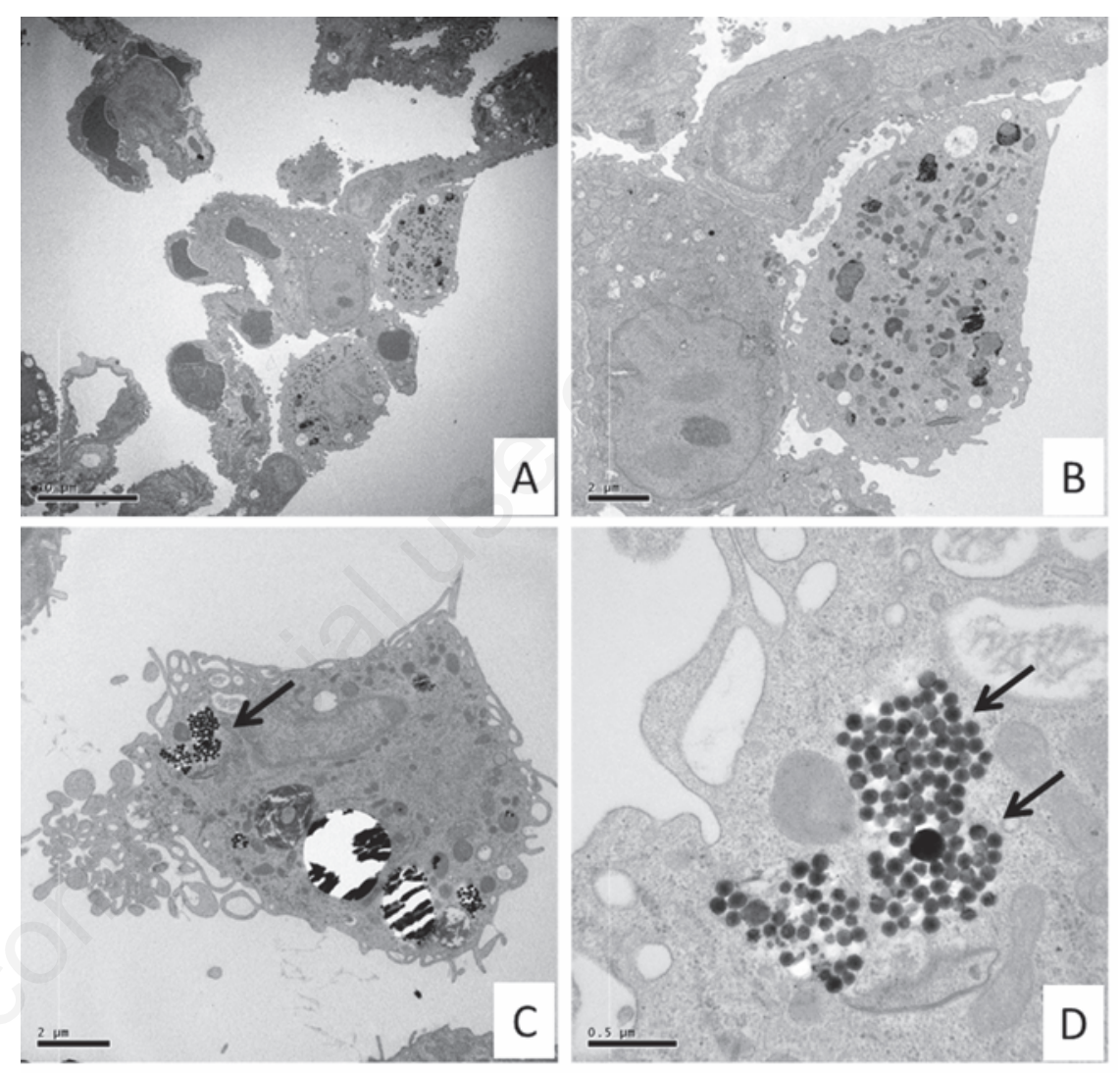

Full scale counts: 959

Lung SiO2

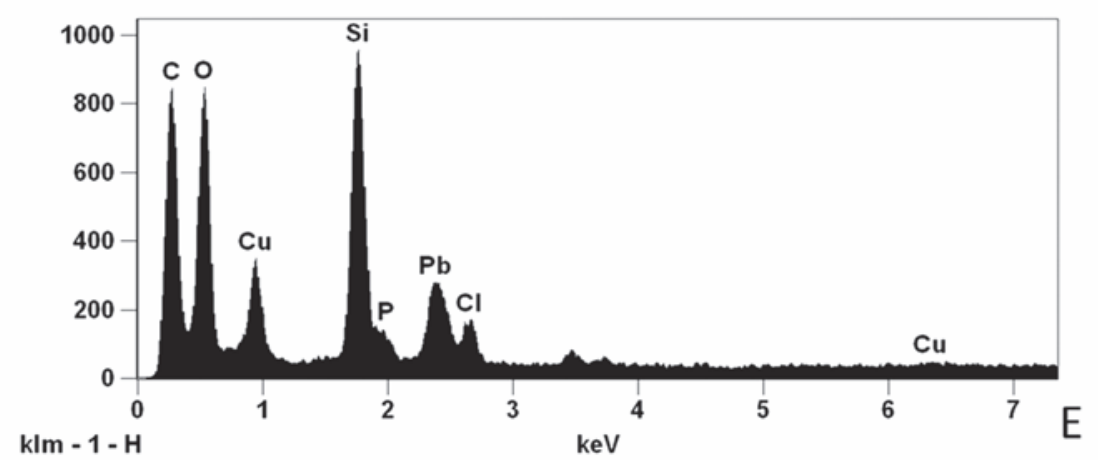

Figure 3. Transmission electron microscopy and EDX microanalysis of murine lung tissues. A) Low magnification of thin walled alveoli (15 day of $\mathrm{SiO} 2$ exposure). B) Histiocyte with a moderate amount of electron dense granules. C,D) Mice lung electron micrographs after 50 day of $\mathrm{SiO}_{2}$ exposure show an elevated amount of small particles (arrows) into the cytoplasm of histiocytes. E) EDX spectrum shows that the particles indicated in the panel $\mathrm{D}$ are made of Si. Other elements can be referred to the composition of the support grid $(\mathrm{Cu})$, staining solution $(\mathrm{Pb})$ and biological tissue $(\mathrm{Cl}, \mathrm{C}, \mathrm{O}$ and P). 
heavy metal particles. At least one of these elements was detected in each NSCLC. However a non-statistically significant difference between adenocarcinomas and squamous cell carcinomas was observed (data not shown). On the contrary, the frequency of accumulation of toxic elements both in BL and in the control group was less and the presence of two or more elements was only occasionally reported. As for the individual elements, $\mathrm{Pb}$ was detected in $86.7 \%$ of NSCLC samples, whereas $\mathrm{Cr}$ and $\mathrm{Co}$ were present in $80 \%$ and $73.3 \%$, respectively. Differences among the three groups for these three elements were statistically significant (Figure 4 A,B,C). As to $\mathrm{Mn}$, the different presence of this element in the three groups was not significant, although the NSCLC tissues still showed higher percentage values (Figure 4D).

A high rate of NSCLC biopsies showed the co-presence of more than one bio-accumulated element. Interestingly, we could find significant differences $(\mathrm{P}<0.0001)$ among the groups, when we compared the bio-accumulation of two or more elements. In particular, at least 2 elements were present in $100 \%$ of NSCLC, $40 \%$ of BL and $20 \%$ of controls (Figure $5 \mathrm{~A}$ ), whereas more than 3 elements were found in $73.3 \%$ of NSCLC and $8.3 \%$ of controls. No BL showed a combination of more than 3 heavy metals (Figure 5B).

\section{Discussion}

Our results demonstrated that the EDX microanalysis is a reliable method to reveal inhaled metal fumes.

The most significant elements accumulated in human lung tissues were $\mathrm{Pb}, \mathrm{Cr}, \mathrm{Co}$ and $\mathrm{Mn}$. It should be noted in particular that these heavy metals coincided with those emitted in the atmosphere by natural and/or anthropic sources. ${ }^{21-23}$ The most frequent element in NSCLC and BL tissue was Pb (Figure 4A). The toxicity of $\mathrm{Pb}$ and its compounds is well-known and is prominently associated with anemia and developmental disorders. Genotoxic and cancerogenic effects of lead compounds are welldocumented in in vitro systems, experimental animal models and in lead exposure studies in humans. ${ }^{14} \mathrm{Co}$ and $\mathrm{Cr}$ were more frequently found in NSCLC (Figure 4 B,C). Exposure to $\mathrm{Cr}$ and Co compounds has been consistently associated with incidences of lung cancers in humans and experimental animals. ${ }^{24}$ Cells of workers exposed to dusts of chromium compounds showed elevated frequencies of DNA strand breaks, ${ }^{25}$ sister-chromatid exchanges and micronuclei. ${ }^{26}$ Inorganic cobalt compounds, both soluble and particulates, caused lung tumors in animal experiments, whereas the
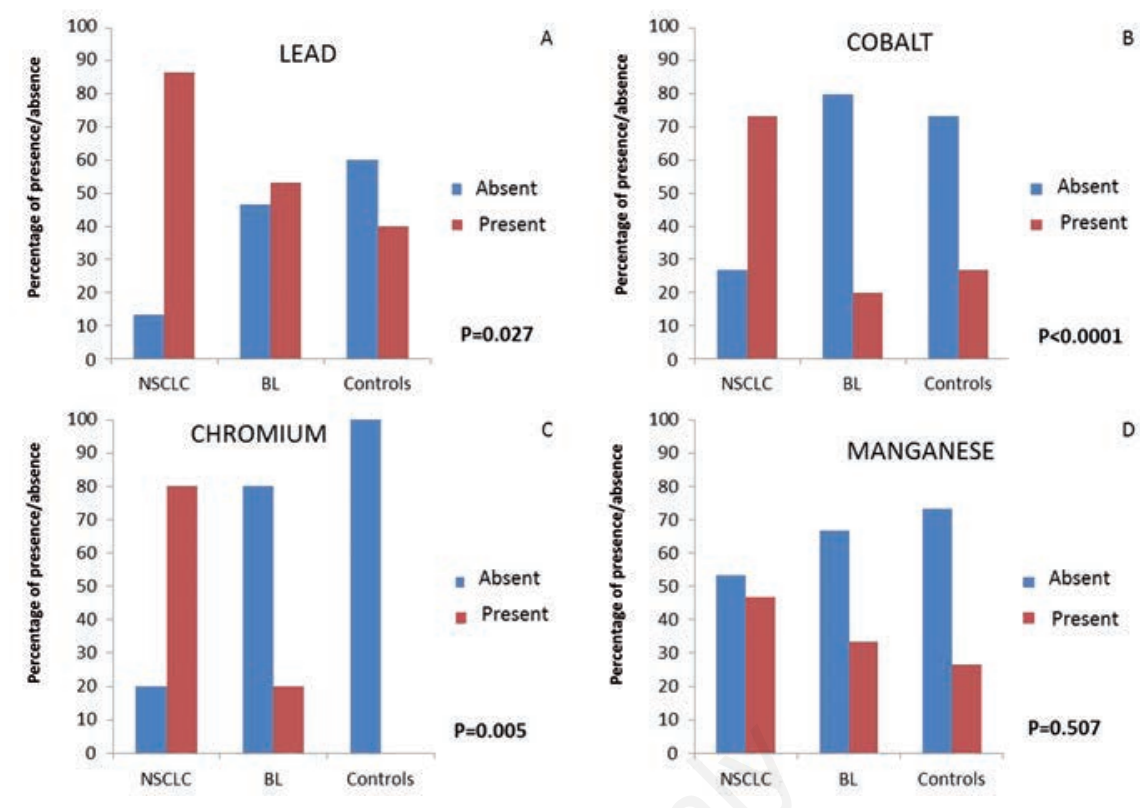

Figure 4. Elemental analysis. Percentage distributions of the four heavy metal according to the three group of tissues: A) lead (Pb); B): cobalt (Co); C): chromium (Cr); D): manganese (Mn). The presence (red column) and absence (blu column) of heavy metal revealed respectively in Non Small Cell Lung Cancer (NSCLC), benign lesions (BL) and control cases (Controls) are reported as percentage. ${ }^{*}$ Chi-Square's test. P-values refer to comparisons among the three groups of tissues according to the presence of each specific element. 
epidemiological findings of the increased lung cancer incidence of cobalt-exposed workers are not regarded as being conclusive, because of the co-exposure to other carcinogenic sub- stances. ${ }^{27}$ In an inhalation carcinogenicity study with cobalt sulfate, mutations in the Kras oncogene were observed in lung tumor tissues of exposed mice. ${ }^{12}$ Moreover, in industrial-

Table 1. Patients characteristics and EDX microanalysis.

\begin{tabular}{|c|c|c|c|}
\hline Lesion & Age & Smoke habit & Elements \\
\hline Adeno-carcinoma & 71 & Yes & $\mathrm{Co} ; \mathrm{Cr} ; \mathrm{Pb}$ \\
\hline Adeno-carcinoma & 58 & Yes & $\mathrm{Co} ; \mathrm{Cr} ; \mathrm{Pb}$ \\
\hline Adeno-carcinoma & 62 & No & $\mathrm{Co} ; \mathrm{Cr} ; \mathrm{Mn}$ \\
\hline Adeno-carcinoma & 56 & Yes & $\mathrm{Co} ; \mathrm{Cr} ; \mathrm{Pb}$ \\
\hline Adeno-carcinoma & 59 & Yes & $\mathrm{Co} ; \mathrm{Cr} ; \mathrm{Mn} ; \mathrm{Pb}$ \\
\hline Adeno-carcinoma & 58 & Yes & $\mathrm{Co} ; \mathrm{Cr} ; \mathrm{Pb}$ \\
\hline Adeno-carcinoma & 49 & Yes & $\mathrm{Mn} ; \mathrm{Pb}$ \\
\hline Adeno-carcinoma & 68 & Yes & $\mathrm{Co} ; \mathrm{Cr} ; \mathrm{Pb}$ \\
\hline Adeno-carcinoma & 62 & Yes & $\mathrm{Co} ; \mathrm{Cr} ; \mathrm{Mn} ; \mathrm{Pb}$ \\
\hline Squamous cell carcinoma & 57 & Yes & $\mathrm{Cr} ; \mathrm{Pb}$ \\
\hline Squamous cell carcinoma & 53 & Yes & $\mathrm{Co} ; \mathrm{Cr}$ \\
\hline Squamous cell carcinoma & 66 & Yes & $\mathrm{Mn} ; \mathrm{Pb}$ \\
\hline Squamous cell carcinoma & 58 & Yes & $\mathrm{Co} ; \mathrm{Mn} ; \mathrm{Pb}$ \\
\hline Squamous cell carcinoma & 64 & Yes & $\mathrm{Cr} ; \mathrm{Pb}$ \\
\hline Squamous cell carcinoma & 61 & No & $\mathrm{Co} ; \mathrm{Cr} ; \mathrm{Mn}$ \\
\hline Chronic interstitial pneumonia & 57 & Yes & $\mathrm{Cr} ; \mathrm{Mn}$ \\
\hline Chronic interstitial pneumonia & 67 & Yes & $\mathrm{Co}_{0}$ \\
\hline Chronic interstitial pneumonia & 82 & Yes & $\mathrm{Pb}$ \\
\hline Chronic interstitial pneumonia & 58 & Yes & $\mathrm{Pb}$ \\
\hline Chronic interstitial pneumonia & 49 & No & $\mathrm{Mn}$ \\
\hline Chronic interstitial pneumonia & 67 & Yes & $\mathrm{Mn} ; \mathrm{Pb}$ \\
\hline Chronic interstitial pneumonia & 77 & No & - \\
\hline Chronic interstitial pneumonia & 64 & Yes & $\mathrm{Pb}$ \\
\hline Idiopathic pulmonary fibrosis & 69 & Yes & $\mathrm{Mn} ; \mathrm{Pb}$ \\
\hline Idiopathic pulmonary fibrosis & 77 & No & Co \\
\hline Idiopathic pulmonary fibrosis & 72 & Yes & $\mathrm{Mn} ; \mathrm{Pb}$ \\
\hline Idiopathic pulmonary fibrosis & 60 & No & - \\
\hline Idiopathic pulmonary fibrosis & 64 & Yes & $\mathrm{Cr} ; \mathrm{Pb}$ \\
\hline Adipose fibrosis & 59 & Yes & $\mathrm{Co} ; \mathrm{Cr}$ \\
\hline Adipose fibrosis & 61 & Yes & $\mathrm{Pb}$ \\
\hline Normal lung tissue & 68 & Yes & $\mathrm{Mn}$ \\
\hline Normal lung tissue & 67 & Yes & $\mathrm{C} 0 ; \mathrm{Mn} ; \mathrm{Mn}$ \\
\hline Normal lung tissue & 75 & No & - \\
\hline Normal lung tissue & 74 & No & - \\
\hline Normal lung tissue & 54 & Yes & $\mathrm{Pb}$ \\
\hline Normal lung tissue & 58 & No & - \\
\hline Normal lung tissue & 65 & Yes & $\mathrm{Pb}$ \\
\hline Normal lung tissue & 57 & No & - \\
\hline Normal lung tissue & 68 & Yes & $\mathrm{Mn} ; \mathrm{Pb}$ \\
\hline Normal lung tissue & 70 & No & Co \\
\hline Normal lung tissue & 71 & Yes & $\mathrm{Mn}$ \\
\hline Normal lung tissue & 58 & No & - \\
\hline Normal lung tissue & 69 & Yes & Co \\
\hline Normal lung tissue & 72 & Yes & $\mathrm{Pb}$ \\
\hline Normal lung tissue & 51 & Yes & $\mathrm{Pb}$ \\
\hline
\end{tabular}

ized countries, car exhaust fumes and cigarette smoke, which are the main sources of pollution impacting on human health, contain traces of all the above-mentioned elements. ${ }^{28}$ Manganese is a transition metal necessary for life processes in trace amounts, but it is toxic at higher doses. ${ }^{15}$ The presence of Mn in NSCLC and BL tissues led us to postulate a relationship with the pathological status (Figure 4D). When Mn particles are present in the atmosphere, their little size $(\leq 10 \mathrm{~nm})$ allows them to easily penetrate into the bronchiole mucosa. Hence, an inflammatory process can start and lead to epithelial inflammation, interstitial pneumonia and granulomatous reactions. ${ }^{29}$ In fact, although it was typically considered a neurotoxin,$^{30}$ excessive Mn has also been associated to increased susceptibility to pulmonary infection, ${ }^{31}$ pulmonary neoplasia, ${ }^{32}$ infant mortality, ${ }^{33}$ and criminal and violent behaviors. ${ }^{34}$

The progressive environmental pollution and the diffusion of inappropriate lifestyles have significantly contributed to the increase in the incidence of lung lesions. Our results show significant differences in the bioaccumulation of toxic elements, such as $\mathrm{Co}, \mathrm{Cr}$ and $\mathrm{Pb}$, between pulmonary cancer lesions (NSCLC) and benign lesions. The ex vivo identification of these toxic elements in the lung tissue could better clarify its environmental impact on lung carcinogenesis. To this aim we used the EDX microanalysis to associate morphological / ultra-structural data with the bio-accumulation of toxic elements related to air pollution. Despite this technology may be difficult to set up and use, it proved particularly efficient for the study of lung tissues.

Lastly, the presence of heavy metals in the examined tissues leaves a fundamental question unanswered: should the bio-accumulation of air pollutant be considered as a primary insult related to tumorigenesis or rather is it due to intrinsic characteristics of the neoplastic tissues which, for unknown reasons, tend to behave as a storage tissue of the elements? As to future prospective research, it would be interesting to verify, through an EDX microanalysis, the possible bio-accumulation of these pollutants and toxic elements in different human organs and systems.

\section{References}

1. Raaschou-Nielsen 0, Andersen ZJ, Beelen R, Samoli E, Stafoggia M, Weinmayr G, et al. Air pollution and lung cancer incidence in 17 European cohorts: prospective analyses from the European Study of Cohorts for Air Pollution Effects (ESCAPE). Lancet Oncol 2013;14:813-22.

2. Schottenfeld D, Fraumeni JF Jr. Cancer 
epidemiology and prevention, 3rd ed. Oxford, Oxford University Press: 2006.

3. Pope CA 3rd, Burnett RT, Thun MJ, Calle EE, Krewski D, Ito K,et al.Lung cancer, cardiopulmonary mortality, and long-term exposure to fine particulate air pollution. JAMA 2002;287:1132-41.

4. Gill EA, Curl CL, Adar SD, Allen RW, Auchincloss AH, O'Neill MS, et al. Air pollution and cardiovascular disease in the multi-ethnic study of atherosclerosis. Prog Cardiovasc Dis 2011;53:353-60.

5. Stanek LW, Brown JS, Stanek J, Gift J, Costa DL. Air pollution toxicology-a brief review of the role of the science in shaping the current understanding of air pollution health risks. Toxicol Sci 2011;120:S8-S27.

6. Castell JV, Donato MT, GómezLechónMJ.Metabolism and bioactivation of toxicants in the lung. The in vitro cellular approach. Exp Toxicol Pathol 2005;57(Suppl.1):189-204.

7. Happo MS, Hirvonen MR, Hälinen AI, Jalava PI, Pennanen AS, Sillanpää M, et al. Seasonal variation in chemical composition of size-segregated urban air particles and the inflammatory activity in the mouse lung. Inhal Toxicol 2010;22:17-32.

8. Kroll A, Gietl JK, Wiesmüller GA, Günsel A, Wohlleben W, Schnekenburger J, et al. In vitro toxicology of ambient particulate matter: correlation of cellular effects with particle size and components. Environ Toxicol 2013;28:76-86.

9. Steenhof M, Gosens I, Strak M, Godri KJ, Hoek G, Cassee FR, et al. In vitro toxicity of particulate matter (PM) collected at different sites in the Netherlands is associated with PM composition, size fraction and oxidative potential--the RAPTES project. Part Fibre Toxicol 2011;8:26.

10. Beyersmann D, Hartwig A. Carcinogenic metal compounds: recent insight into molecular and cellular mechanisms. Arch Toxicol 2008;82:493-512.

11. Rehfisch P, Anderson M, Berg P,Lampa E, Nodling Y, Svartengren M, et al. Lung function and respiratory symptoms in hard metal workers exposed to cobalt. J Occup Environ Med 2012;54:409-13.

12. National Toxicology Program. Toxicology and carcinogenesis studies of cobalt sulfate heptahydrate in F334/N rats and B6C3F1 mice (inhalation studies). Natl Toxicol Program Tech Rep Ser 1996;451:1-381.
13. International Agency for Research on Cancer. Chromium, nickel and welding, $p$. 49-256. In: IARC monographs on the evaluation of carcinogenic risks to humans, vol. 49. Lyon, IARC: 1990.

14. International Agency for Research on Cancer. Inorganic and organic lead compounds. IARC monographs on the evaluation of carcinogenic risks to humans, vol. 87. Lyon, IARC: 2006.

15. Spangler JG, Reid JC. Environmental manganese and cancer mortality rates by county in North Carolina: an ecological study. Biol Trace Elem Res 2010;133:128-35.

16. Carson FL. Histotechnology: a self-instructional text. Chicago, ASCP Press: 1997.

17. Orlandi A, Marcellini M, Spagnoli LG. Aging influences development and progression of early aortic atherosclerotic lesions in cholesterol-fed rabbits. Arterioscler Thromb Vasc Biol 2000;20: 1123-36.

18. Dykstra MJ. Biological electron microscopy: theory, techniques and troubleshooting. New York, Plenum Press: 1992.

19. Reynolds ES. The use of lead citrate at high $\mathrm{pH}$ as an electron opaque stain based on metal chelation. J Cell Biol 1963;17:208-12.

20. Scimeca M, Anemona L, Colantoni A, Bonanno E. Ultrastructural and microanalytical study of a subcutaneous granuloma HPV tetravalent vaccine induced: a case report and review of literature. $\mathrm{J}$ Med Cases 2013;7:461-5.

21. Bell ML, Ebisu K, Peng RD, Dominici F. Adverse health effects of particulate air pollution: modification by air conditioning. Epidemiology 2009;20:682-6.

22. Domagala-Kulawik J. Effects of cigarette smoke on the lung and systemic immunity. J Physiol Pharmacol 2008;59(Suppl.6): 1934.

23. Srimuruganandam B, Nagendra SM. Chemical characterization of PM10 and PM2.5 mass concentrations emitted by heterogeneous traffic. Sci Total Environ 2011;409:3144-57.

24. International Agency for Research on Cancer. Chlorinated drinking water; chlorination byproducts; some other halogenated compounds; cobalt and cobalt compounds, p. 363-472. In: IARC monographs on the evaluation of carcinogenic risks to humans, vol. 52. Lyon, IARC: 1991.

25. Gambelunghe A, Piccinini R, Ambrogi M, VillariniM, Moretti M, Marchetti C, et al.
Primary DNA damage in chrome-platingworkers.Toxicology 2003;188:187-95.

26. Kasprzak KS, Zastawny TH, North SL, Riggs CW, Diwan BA, Rice JM, et al. Oxidative DNA base damage in renal, hepatic, and pulmonary chromatin of rats after intra-peritoneal injection of cobalt(II) acetate. Chem Res Toxicol 1994; 7:329-35.

27. International Agency for Research on Cancer. Cobalt in hard metals and cobalt sulfate, gallium arsenide, indium phosphide and vanadium pentoxide, p. 119-237. In: IARC monographs on the evaluation of carcinogenic risks to humans, vol. 86 . Lyon, IARC: 2006.

28. Rustemeier K, Stabbert R, Haussmann HJRoemer E, Carmines EL. Evaluation of the potential effects of ingredients added to cigarettes. Part 2: chemical composition of mainstream smoke. Food Chem Toxicol 2002;40:93-104

29. Michalke B, Berthele A, Mistriotis P, Ochsenkühn-Petropoulou M, Halbach S. Manganese species from human serum, cerebrospinal fluid analyzed by size exclusion chromatography-, capillary electrophoresis coupled to inductively coupled plasma mass spectrometry. J Trace Elem Med Biol 2007;21(Suppl.1):4-9.

30. Agency for Toxic Substances and Disease Registry. Toxicological profile for manganese (Draft for public comment). Atlanta, U.S. Department of Health and Human Services, Public Health Service: 2008.

31. Hanzlik RP, Bhatia P, Stitt R, Traiger GJ. Biotransformation and excretion of methylcyclopentadienyl manganese tricarbonyl in the rat. Drug Metab Dispos 1980;8:428-33.

32. Stoner GD, Shimkin MB, Troxell MC, Thompson TL, Terry LS. Test for carcinogenicity of metallic compounds by the pulmonary tumor response in strain A mice. Cancer Res 1976;36:1744-7.

33. Hafeman D, Factor-Litvak P, Cheng Z, van Geen A, Ahsan H. Association between manganese exposure through drinking water and infant mortality in Bangladesh. Environ Health Perspect 2007;115:1107-12.

34. Gottschalk LA, Rebello T, Buchsbaum MS, Tucker HG, Hodges EL. Abnormalities in hair trace elements as indicators of aberrant behavior. Compr Psychiatry 1991;32: 229-37. 